\title{
Model Prakiraan Harga dan Permintaan pada Rantai Pasok Karet Spesifikasi Teknis Menggunakan Jaringan Syaraf Tiruan
}

\author{
Nofi Erni ${ }^{*}$, M. Syamsul Maarif ${ }^{2}$, Nastiti S.Indrasti ${ }^{2}$, Machfud $^{2}$, Soeharto Honggokusumo $^{3}$ \\ ${ }^{1}$ Mahasiswa Pascasarjana S3 Departemen Teknologi Industri Pertanian, FATETA, IPB, Bogor \\ ${ }^{2}$ Departemen Teknologi Industri Pertanian, FATETA, IPB, Bogor \\ ${ }^{3}$ Peneliti dan Direktur GAPKINDO, Jakarta \\ "Penulis untuk korespondensi: nofierni@yahoo.co.id
}

Abstrak - Karet spesifikasi teknis (TSR) merupakan jenis karet alam yang penting, dengan pertumbuhan permintaan yang tinggi dibanding jenis karet alam yang diproduksi dan diekspor oleh Indonesia. TSR paling banyak digunakan sebagai bahan baku untuk industri ban, sehingga dengan tumbuhnya indutri otomotif mendorong peningkatan permintaan terhadap TSR. Namun permasalahan muncul dalam produksi TSR, dimana tingkat fluktuasi baik karena kelebihan maupun kekurangan produksi sangat berpengaruh terhadap perubahan harga TSR di pasar Internasional. Untuk mengurangi fluktuasi tersebut diperlukan suatu metode untuk memperkirakan tingkat permintaan dan harga. Penelitian ini bertujuan untuk merancang suatu metode prakiraan yang dapat merperkirakan tingkat harga dan volume permintaan untuk TSR 20. Prakiraan dilakukan dengan Jaringan Syaraf Tiruan (JST) dengan algoritma propagasi balik, menggunakan data perkembangan pasar TSR di bursa berjangka SICOM. Model JST yang dirancang mempertimbangkan pola harga, pola permintaan dan interaksi kedua faktor. Hasil simulasi menunjukkan penggunaan 5 input neuron yaitu: 1) harga tertinggi, 2) harga terendah, 3) harga penutupan, 4) volume permintaan awal, 5) volume permintaan penutupan, 15 neuron pada lapisan tersembunyi dan 2 output yaitu harga dan volume permintaan pada lapisan output. Tingkat akurasi hasil prakiraan harga mencapai $91 \%$ dan akurasi prakiraan permintaan $87 \%$. Berdasarkan hasil prakiraan ditentukan status harga dan permintaan. Harga tinggi jika perbedaan antara nilai maksimum dan nilai tengah lebih tinggi dari $47 \%$, harga rendah jika perbedaan antara nilai minimum dan nilai tengah lebih dari $20 \%$. Prakiraan permintaan dinyatakan tinggi atau rendah jika terjadi peningkatan maupun penurunan sebesar $50 \%$ dari rata-rata permintaan.

Abstrack - Technically Specified Rubber (TSR) is the most important of natural rubber type which has a high demand growth which is produced and exported by Indonesia. TSR is mostly used as raw material for tire industries, as the world's automotive industries grow up the demand for TSR is also rise up. However, the problem appears in the production of TSR, which is fluctuative production rate in the form of over and under production correlated to the price change in International market. Therefore, a method to forecast the price and demand level is needed to design in order to reduce fluctuation. The result is a forecasting that used as an input for preparing and adjusting TSR rubber production planning that working adaptively with market condition by utilising the expert knowledge. This research aimed to design a method that can forecast the changes in price level and demand volume. Artificial Neural Network (ANN) which is backpropagation algorithm that has been designed according to data TSR market condition in SICOM is used in this research, the ANN model is modified by observing the price pattern, demand pattern and the connection between both of them together. Experiments have shown that the optimal architecture network for price and demand forecasting can be obtained by using 5 different neuron parameter, there are: 1) the highest price, 2) the 
lowest price, 3) the closing price, 4) demand volume interest, 5) demand volume close for input layer, 15 neuron for hidden layer and 2 different neuron there are price and demand volume for output layer. The accuracy of forecasting price had reached $91 \%$ and $87 \%$ for forecasting demand. Based on forecasting result had determined the state of price and demand. The price is high if the differences between maximum and mean score is higher than $47 \%$ and the price is low if the differences between the minimum and mean score is higher than $20 \%$. The demand is high if the demand forecasting is higher than $50 \%$ and it is low if smaller than $50 \%$ of average demand volume.

Keywords - Artificial Neural Network, Technically Specified Rubber, Forecasting, Supply Chain.

\section{PENDAHULUAN}

\begin{abstract}
groindustri karet alam memiliki peran strategis A sebagai sumber devisa negara, sumber lapangan kerja, pemasok bahan baku industri barang jadi karet. Indonesia merupakan negara dengan areal perkebunan karet terluas di dunia namun merupakan penghasil karet alam nomr dunia setelah Thailand. Pada tahun 2010 luas areal perkebunan karet mencapai 3,44 juta hektar dengan produksi karet sebanyak 2,59 juta ton yang sebagian besar diekspor [1].
\end{abstract}

Ekspor karet alam Indonesia pada tahun 2010 mencapai nilai 7,32 milyar US\$ dengan kontribusi terbesar dalam bentuk karet spesifikasi teknis (Technically Spesified Rubber, TSR) dibanding jenis karet alam lainnya. Ekspor karet spesifikasi teknis dengan kodifikasi Standar Indonesian Rubber jenis SIR 20 mencapai $92 \%$ dari total ekspor karet alam Indonesia dengan volume ekspor sebesar 2,16 juta ton.

Karet alam jenis TSR 20 sebagian besar digunakan sebagai bahan baku pada pembuatan ban. Pertumbuhan industri otomotif yang relatif pesat setelah krisis global pada tahun 2008-2009, mendorong pertumbuhan konsumsi karet alam dunia sehingga memberikan peluang untuk meningkatkan produksi karet alam khususnya jenis karet spesifikasi teknis untuk memenuhi kebutuhan industri hilir khususnya industri ban [2].
Salah satu permasalahan utama dalam rantai pasok agroindustri karet spesifikasi teknis di Indonesia adalah tidak seimbangnya pertumbuhan produksi dengan pertumbuhan permintaan karet dunia. Ketidakseimbangan produksi dengan permintaan selain disebabkan oleh rendahnya kemampuan produksi dibandingkan pertumbuhan permintaan, sehingga menimbulkan ketidakstabilan harga. Untuk menjaga kestabilan harga sebagai akibat kekurangan dan kelebihan produksi yang tidak sejalan dengan konsumsi karet dunia agroindustri penghasil karet alam dibutuhkan suatu sistem perencanaan produksi yang fleksibel dan adaptif terhadap kondisi permintaan pasar.

Berdasarkan kondisi ini perlu dikembangkan penelitian untuk merekayasa suatu model prakiraan permintaan dan harga karet spesifikasi teknis. Model prakiraan sebagai langkah awal kegiatan perencanaan produksi diharapkan dapat meminimalkan resiko kelebihan maupun kekurangan produksi yang secara langsung mengakibatkan fluktuasi harga. Model prakiraan pada penelitian ini dirancang dengan mempertimbangkan fluktuasi dari faktor harga dan volume permintaan karet spesifikasi teknis dalam perdagangan komoditas. Metode yang digunakan adalah metode Jaringan Syaraf Tiruan dengan mengakomodir pola pengaruh dari permintaan dan harga secara bersama-sama.

Tujuan perancangan model prakiraan harga dan permintaan karet jenis TSR 20 adalah menghasilkan model dalam bentuk program komputasi yang dapat digunakan untuk (1) membuat prakiraan harga dan volume permintaan TSR 20 di pasar komoditas, (2) menentukan klasifikasi tingkat harga dan volume permintaan. Model prakiraan ini diharapkan bermanfaat bagi pabrik sebagai pengolah dalam menyesuaikan rencana produksi pada manajemen rantai pasok dengan pertimbangan harga dan tingkat permintaan yang lebih tepat. Penelitian ini diharapkan bermanfaat untuk penambahan khasanah pengetahuan yang berkaitan dengan metode prakiraan khususnya untuk memprediksi kondisi yang akan datang dengan mempertimbangkan beberapa faktor dan interaksinya dalam melakukan prakiraan. 


\section{TINJAUAN PUSTAKA}

Prakiraan tingkat permintaan merupakan langkah awal dalam perencanaan produksi. Prakiraan permintaan dalam mengelola rantai pasok perlu mempertimbangkan sinkronisasi antara sisi permintaan dan pasokan. Berbagai definisi tentang prakiraan (forecasting) telah dikembangkan, secara garis besar prakiraan adalah proses menganalisis data historis yang diproyeksikan ke dalam sebuah model untuk memperkirakan keadaan di masa mendatang [3].

Teknik peramalan yang relatif banyak digunakan dalam melakukan prakiraan untuk menyusun rencana produksi adalah 1) metode pemulusan, 2) metode ARIMA, 3) metode Fourier dan 4) metode Jaringan Syaraf Tiruan. Beberapa hal yang perlu dipertimbangkan dalam memilih metode adalah kesesuaian metode dengan kondisi nyata yang dimodelkan dan mampu mengakomodir faktor-faktor yang mempengaruhinya, seperti harga dan pasokan.

Penelitian yang berkaitan dengan perencanaan produksi pada rantai pasok relatif beragam dengan penggunaan teknik kecerdasan buatan seperti logika fuzzy, algoritma genetik dan jaringan syaraf tiruan dalam mengelola rantai pasok telah dikembangkan. Prakiraan permintaan pada umumnya dilakukan dengan menggunakan data time series. Penelitian yang berkaitan dengan prakiraan produksi karet alam telah dilakukan peneliti terdahulu. Pengujian dilakukan terhadap empat metode yaitu metode trend, Holts, Winters dan ARIMA dengan ukuran kinerja adalah mean absolute percentage error (MAPE) untuk memperkirakan produksi karet alam di India.

Penggunaan metode Jaringan Syaraf Tiruan (JST) dalam melakukan prediksi atau prakiraan telah banyak dilakukan. Salah satu metode JST yang paling banyak digunakan adalah JST dengan algoritma propagasi balik (backpropagation).

Prinsip metode JST dalam melakukan mengolah informasi mengikuti cara bekerja jaringan syaraf otak manusia. Informasi yang diterima ditransformasikan melalui beberapa neuron. Dasar komputasi JST melibatkan jaringan, input, lapisan tersembunyi, output, bobot dan fungsi aktivasi. Berdasarkan pola pembelajaran dalam melakukan generalisasi dikenal metode JST backpropagation (Gambar 1).

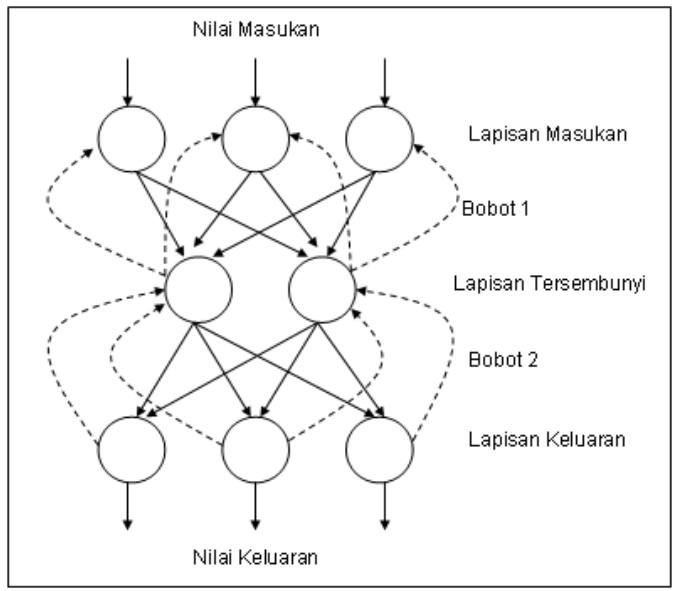

Gambar 1. Arsitektur JST backpropagation

Metode JST backpropagation merupakan metode JST dengan algoritma pembelajaran terawasi (supervised). Prinsip kerja metode ini adalah menghitung besarnya output error berdasarkan input data yang diberikan menggunakan fungsi aktivasi yang sesuai berdasarkan nilai target yang ditetapkan.

Implementasi JST untuk memprediksi permintaan komoditi agroindustri berdasarkan data permintaan masa lalu telah dilakukan [4] untuk akar wangi dan untuk prediksi beras oleh [5]. Penggunan teknik JST dalam memprediksi produksi karet alam di Indonesia diperlukan untuk meningkatkan kinerja pengelolaan rantai pasok karet alam sehingga dapat dihasilkan suatu rencana produksi yang lebih efektif dan efisien

Menurut [6] kelebihan metode JST dalam melakukan prakiraan adalah 1) memiliki kemampuan belajar melalui penyesuaian bobot dalam struktur jaringan untuk setiap proses pembelajarannya, 2) memiliki kemampuan generalisasi sehingga mampu mempelajari pola baru mengacu pada pola pembelajaran yang diberikan, 3) mampu menyelesaikan masalah nonlinier yang sulit diselesaikan dengan model matematis, selama jaringan mampu mempelajari pola non linier yang dilatihkan dan 4) memiliki kehandalan dalam menangani sejumlah noise pada input, bahkan jika terjadi kerusakan dalam arsitektur jaringan, JST masih dapat melakukan tugasnya dalam batas tertentu.

Untuk mendukung pengembangan sistem perencanaan produksi pada agroindustri karet spesifikasi teknis perlu direkayasa suatu model prakiraan permintaan dan harga dengan 
mempertimbangkan kondisi perdagangan karet dunia. Berdasarkan hasil prakiraan harga dan permintaan dalam perdagangan karet global maka disusun suatu rencana produksi yang mempertimbangkan kebutuhan bahan baku dan kemampuan pabrik dalam berproduksi.

\section{METODE PENELITIAN}

Penelitian perancangan model prakiraan permintaan dan harga Karet Spesifikasi Teknis jenis TSR 20 dikembangkan dengan menggunakan metode Jaringan Syaraf Tiruan (JST). Penelitian dilakukan di PT. Kharisma Pemasaran Bersama Nusantara (KPBN) yang berlokasi di Jakarta sebagai instansi yang melaksanakan fungsi pemasaran dari produk yang dihasilkan oleh PTPN (PT Perkebunan Nusantara).

Data yang digunakan untuk verifikasi dan validasi model adalah data penjualan harian TSR 20 tahun 2010 pada pasar berjangka SICOM (Singapore Commodity Exchange) untuk menyusun klasifikasi tingkat harga dan permintaan. Hasil prakiraan tersebut dijadikan sebagai salah satu input untuk merekayasa sistem manajemen ahli perencanaan produksi untuk menghasilkan rencana produksi TSR 20 di pabrik pengolahan milik salah satu PT Perkebunan Nusantara milik negara.

Diagram alir tahapan perancangan JST untuk prakiraan harga dan prakiraan permintaan karet alam TSR 20 disajikan pada Gambar 2. Rancangan JST terbaik adalah hasil simulasi yang menunjukkan nilai parameter output berupa mean square error (MSE), jumlah iterasi (epoch), dan koefisien regresi terbaik. Beberapa parameter yang diuji adalah fungsi aktivasi, algoritma pelatihan dan momentum. Pengolahan data menggunakan paket program Mathlab versi 2.09 dengan menggunakan lima input parameter yang berbeda.

\subsection{Perancangan Model}

Rekayasa model prakiran harga dan volume permintaan yang dikembangkan merupakan bagian dari model sistem manajemen ahli perencanaan produksi untuk pengelolaan rantai pasok karet spesifikasi teknis jenis TSR 20. Hasil perancangan model prakiraan ini akan menjadi input untuk merekayasa Sistem Manajemen Ahli (SMA) perencanaan produksi sebagai bentuk komprehensif penelitian yang akan dikembangkan.
Tahapan perancangan dimulai dengan merancang arsitektur JST yang sesuai, dilanjutkan dengan menentukan klasifikasi harga dan volume sebagai masukan untuk membentuk mekanisme inferensi dengan logika If Then Rule dalam model Sistem Manajemen Ahli yang dirancang bangun pada penelitian selanjutnya

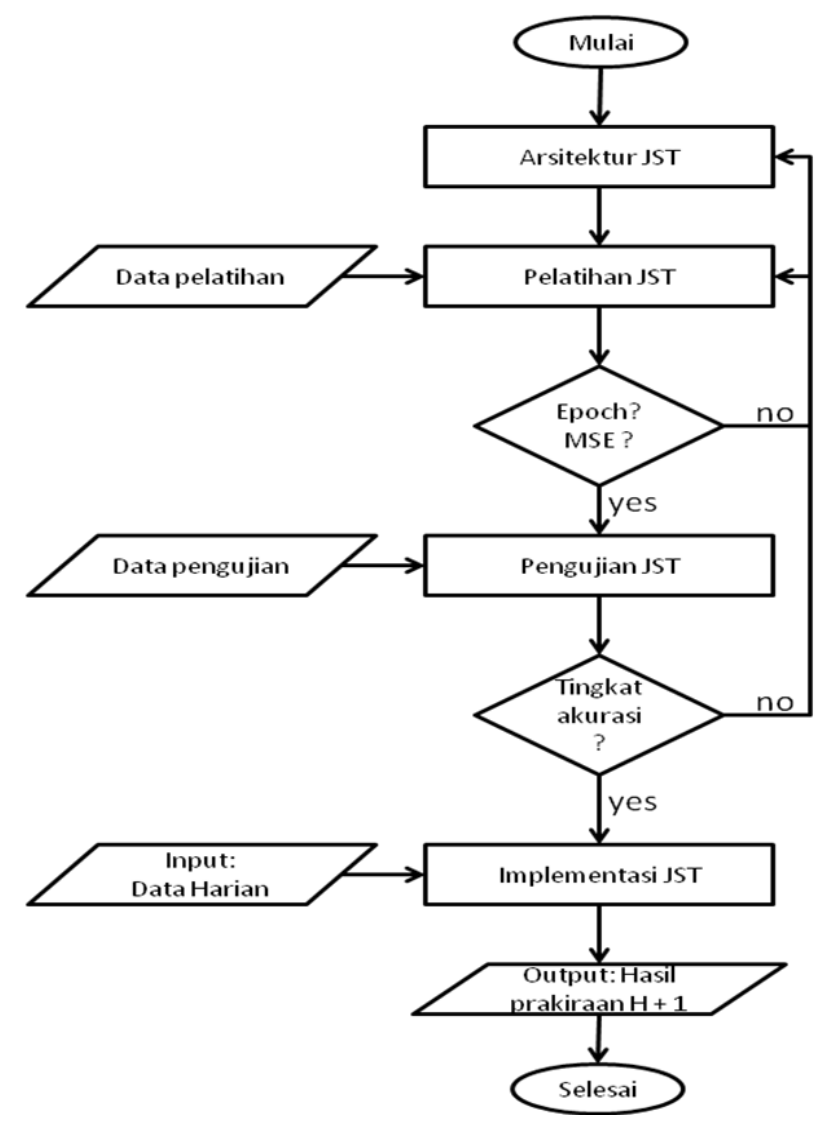

Gambar 2. Tahap Perancangan JST Prakiraan Harga dan Volume Permintaan SIR- 20

\subsection{Tahap Perancangan JST}

Algoritma yang digunakan adalah backpropagation dengan lapisan tersembunyi tunggal (single hidden layer). Algoritma backpropagation banyak digunakan karena kemampuannya dalam mengenali pola data yang digunakan selama pelatihan serta kemampuan jaringan untuk memberikan respon yang benar terhadap pola data input dengan pola yang dipakai selama pelatihan. Algoritma ini pada umumnya menggunakan satu lapisan tersembunyi namun juga bisa ditambahkan beberapa layar tersembunyi dinatara input layer dan output layer. Algoritma backpropagation merupakan algoritma pembelajaran terawasi (supervised learning) dan terdiri atas tiga tahapan yaitu 1) fase feedforward (propogasi maju) pola input pelatihan, 2) fase 
penghitungan dan backpropagation error dan 3) fase penyesuaian bobot supaya output mendekati target [7].

Pada fase feedforward, sinyal masukan dipropagasikan ke lapisan tersembunyi menggunakanfungsi aktivasi. Keluaran dari layar tersembunyi dibandingkan dengan target yang harus dicapai. Selisih antara keluaran dan target merupakan nilai kesalahan (error). Jika nilai kesalahan lebih kecil dari batas toleransi yang ditetapkan, maka iterasi dihentikan, namun jika nilai kesalahan lebih besar dari batas toleransi, dilakukan modifikasi bobot untuk setiap garis dalam jaringan. Pada fase backpropagation dilakukan penghitungan faktor untuk mendistribusikan kesalahan pada semua lapisan. Selanjutnya pada fase penyesuaian bobot dilakukan modifikasi bobot semua garis sehingga mendekati nilai target . Ketiga fase tersebut diulangi sehingga kondisi yang ditargetkan tercapai baik berupa jumlah iterasi (epoch) yang ditetapkan atau jika nilai kesalahan yang terjadi lebih kecil dari toleransi yang diijinkan [7].

Mekanisme algoritma backpropagation bekerja dengan menggunakan error output untuk melakukan perubahan nilai bobot dalam arah mundur. Error output diperoleh melalui tahap forward propagation dengan mengaktifkan neuronneuron menggunakan fungsi aktivasi. Parameter output untuk menentukan kinerja simulasi pada model ini adalah Mean Square Error (MSE), jumlah iterasi (epoch) dan koefisien korelasi. Mengacu pada [7] untuk mendapatkan hasil perancangan JST terbaik dengan algoritma backpropagation perlu dilakukan penentuan fungsi aktivasi, algoritma training, lapisan tersembunyi dan nilai target seperti toleransi error dan jumlah iterasi.

Perancangan arsitektur jaringan model prakiraan harga dan permintaan dalam penelitian ini dirancang melalui tahapan berikut ini:

\section{a. Menentukan Fungsi Aktivasi}

Fungsi aktivasi dalam backpropagation harus memenuhi syarat yaitu; kontinyu, terdiferensial dengan mudah dan merupakan fungsi yang tidak turun [7]. Pada perancangan arsitektur JST dalam penelitian ini fungsi aktivasi yang digunakan adalah :

1. Sigmoid biner (logsig)

Formula untuk fungsi sigmoid biner adalah:

$\operatorname{logsig}(n)=1 /\{1+\exp (-n)\}$
2. Sigmoid bipolar (tansig)

Formula untuk fungsi sigmoid bipolar adalah:

$\operatorname{tansig}(n)=2 /\{1+\exp (-2 * n)-1\}$

3.Purelin (identitas)

Formula untuk fungsi purelin adalah: purelin $(\mathrm{n})=\mathrm{n}$

\section{b. Memilih Algoritma Training}

Pada tahap pelatihan perlu ditentukan parameter untuk melakukan simulasi, diantaranya adalah arsitektur jaringan, nilai momentum dan target. Agar pelatihan berjalan lebih cepat dalam proses pembelajaran menggunakan jaringan backpropagation dapat digunakan metode penurunan gradien (traingd), dengan cara 1) penambahan momentum (traingdm), 2) momentum dan learning rate (traingdx), 3) Levenberg-Marquadt (trainglm), 4) Resilient Backpropagation [7]. Momentum merupakan perubahan bobot yang berdasarkan pada arah gradien pola terakhir dan pola data yang dimasukkan sebelumnya.

Untuk menentukan nilai momentum dapat dilakukan dengan trial and error. Nilai momentum yang dapat digunakan antara 0 dan 1 [7]. Nilai momentum dapat ditingkatkan untuk menghindari perubahan bobot yang terlalu dratis, sebagai akibat adanya data yang berbeda secara signifikan dengan data-data lain. Pada penelitian ini proses pelatihan menggunakan $70 \%$ dari pola data dan proses pengujian menggunakan $30 \%$ pola data yang menggunakan 50 set data rata-rata mingguan yang diambil dari data transaksi harian di bursa komoditas SICOM tahun 2010.

\section{c. Menentukan Lapisan Tersembunyi}

Lapisan tersembunyi berguna untuk mengenali pola data, pada tahapan ini ditentukan jumlah lapisan (layer) dan jumlah neuron (ukuran layer). Secara teoritis dinyatakan bahwa jaringan dengan satu lapisan tersembunyi cukup memadai untuk mengenali sembarang pemetaan antara pola masukan dan target dengan tingkat akurasi yang ditetapkan [7]. Penentuan jumlah lapisan tersembunyi dilakukan secara trial and error dengan mengacu kepada beberapa alternatif fungsi aktivasi, jumlah neuron serta indikator (target) yang ingin dicapai. 


\section{d. Menentukan Target Nilai Kesalahan}

Target nilai kesalahan (error) adalah parameter yang ditentukan sehingga iterasi dapat dihentikan. Iterasi akan berhenti bila nilai error lebih kecil dari batas yang ditentukan atau jumlah epoch sudah mencapai batas yang ditentukan. Indikator nilai kesalahan pada JST backpropagation pada umumnya berdasarkan kuadrat rata-rata kesalahan (Mean Square Error,MSE) yang dijadikan sebagai nilai target (goal). Pada penelitian ini nilai MSE yang ditargetkan adalah 0,00001. Selain target kesalahan indikator pencapaian dibatasi dari jumlah iterasi (epoch) sebanyak 5.000 kali iterasi.

\section{HASIL DAN PEMBAHASAN}

Perancangan model prakiraan harga dan volume permintaan untuk karet alam jenis TSR 20 dapat dilakukan dengan menggunakan metode Jaringan Syaraf Tiruan backpropagation. Hasil simulasi menggunakan data transaksi harian sepanjang tahun 2010 pada bursa komoditi SICOM. Untuk mendapatkan input yang dijadikan masukan dalam pelatihan dan pengujian dihitung rata-rata harian yang dikelompokkan menjadi rata-rata mingguan.

Arsitektur JST backpropagation yang banyak digunakan dalam peramalan pada umumnya menggunakan input neuron dengan satu parameter yang sama seperti yang dikembangkan dalam model prakiraan harga dan prakiraan permintaan oleh [4] dan prakiraan harga dan permintaan beras oleh [5], dimana prakiraan permintaan dan prakiraan harga menggunakan model yang terpisah.

Berbeda dengan penelitian terdahulu penelitian ini menggunakan 5 neuron dengan parameter yang berbeda yang secara serempak digunakan dalam satu model, sehingga terdapat interaksi antara 5 pola data input yang digunakan. Parameter untuk input layer tersebut adalah 1) harga tertinggi, 2) harga terendah, 3) harga penutupan, 4) volume penutupan dan 5) volume pembukaan. Keluaran dari hasil rancangan JST pada penelitian ini adalah 1) prakiraan harga dan 2) prakiraan volume permintaan.

Arsitektur JST terbaik yang dihasilkan pada penelitian diperoleh pada rancangan (spesifikasi) ke 15 yang disajikan pada Tabel 1. Pada arsitektur ini fungsi aktivasi pada input layer adalah transig, pada hidden layer adalah logsig dengan algoritma pelatihan trainml. Berdasarkan tiga indikator pelatihan yang dijadikan acuan dalam pemilihan arsitektur terbaik, spesifikasi ke 15 tidak perlu melakukan pelatihan sampai epoch maksimum. Pada epoch ke 50 target (goal) sudah tercapai dengan nilai MSE mencapai 0,0000919 dan nilai koefisien regresi mencapai 0,9977 .

Penggunaan MSE sebagai nilai target dibanding metode perhitungan nilai error lain memiliki keunggulan karena nilai error baik dalam arah negatif maupun arah positif dikuadratkan sehingga total jumlah error diakomodir dalam total error model.

Berdasarkan arsitektur terbaik dilakukan prediksi untuk harga dan volume permintaan untuk periode 16 minggu yang akan datang. Hasil prakiraan harga dan prakiraan volume permintaan dan tingkat akurasi disajikan pada Tabel 2. Tingkat ketelitian hasil prakiraan harga mencapai $91 \%$ sedangkan akurasi prakiraan volume permintaan mencapai $87 \%$. Akurasi volume permintaan lebih rendah karena fluktuasi data volume permintaan pada saat pembukaan pada beberapa periode berbeda drastis dengan pola saat penutupan.

Pencapaian tingkat akurasi pada prakiraan harga dan volume permintaan selanjutnya digunakan untuk memprediksi parameter harga dan volumen permintaan periode yang akan datang. Fluktuasi yang cukup besar seperti yang terjadi dalam pasar komoditas di SICOM sangat dipengaruhi isu-isu yang berkaitan dengan pertumbuhan industri otomotif sejalan dengan perubahan yang terjadi dalam perekonomian global seperti pengaruh harga minyak bumi, harga karet sintetis maupun kondisi perekonomian di negara pengimpor. Faktor iklim di negara produsen karet alam juga menentukan tingkat produksi yang pada akhirnya berpengaruh terhadap harga karet alam.

Hasil simulasi untuk memeperoleh rancangan JST untuk prakiraan harga dan permintaan TSR 20 dengan Mathlab sebagai contoh ilustrasi disajikan pada Gambar 3.

Berdasarkan 5 input parameter harga dan volume permintaan dapat dihitung prakiraan untuk harga dan volume permintaan untuk 16 minggu akan datang. 


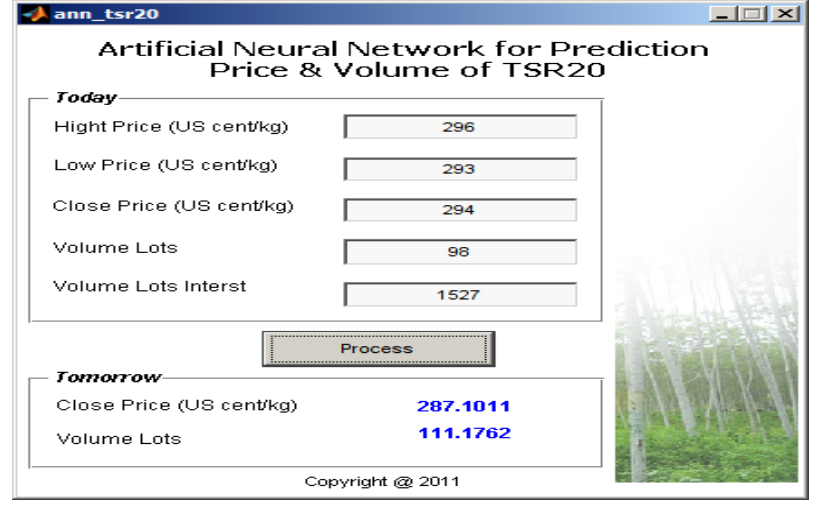

Gambar 3. Tampilan JST untuk Prakiraan Harga dan Permintaan TSR 20

Hasil prakiraaan harga dan prakiraan volume permintaan dibandingkan dengan harga rata-rata untuk memperoleh klasifikasi aturan yang akan digunakan sebagai input untuk menyusun aturan pada sistem manajemen ahli perencanaan produksi yang akan dirancang. Perhitungan selisih antara nilai maksimum prakiraan dengan nilai rata- rata dinyatakan sebagai kategori tinggi, sementara selisih antara nilai rata-rata dengan nilai minimum dinyatakan sebagai kategori rendah. Kondisi normal adalah kondisi diantara kategori tinggi dan rendah. Keseluruhan kategori harga dan permintaan disajikan pada Tabel 3.

\section{KESIMPULAN}

Berdasarkan hasil perancangan model prakiraan ini dapat disimpulkan:

1. Arsitektur jaringan syaraf tiruan backpropagation dengan satu layar tersembunyi, menggunakan lima neuron yang memiliki parameter berbeda pada input layer dan dua neuron dengan atribut berbeda pada ouput layer dapat dirancang sebagai untuk memprediksi tingkat harga dan volume permintaan karet spesifikasi teknis jenis TSR 20.

2. Rancangan JST backpropagation dengan menggunakan neuron input berupa 1) harga tertinggi, 2) harga terendah, 3) harga penutupan, 4) volume minat permintaan, 5) volume penutupan penjualan dapat menghasilkan prakiraan untuk harga dan volume permintaan yang akan datang, Tingkat ketelitian untuk prakiraan harga mencapai $91 \%$ sedangkan akurasi prediksi permintaan sebesar $87 \%$.
3. Berdasarakan selisih harga maksimum dan harga rata-rata serta selisih harga rata-rata dengan harga minimum maka harga TSR 20 dinyatakan tinggi jika melebihi $47 \%$ harga ratarata, dan dinyatakan rendah jika kurang dari $20 \%$ harga rata-rata TSR 20.

4. Hasil selisih volume permintaan maksimum dan volume rata-rata serta selisih volume permintaan rata-rata dengan volume minimum maka volume permintaan TSR 20 dinyatakan tinggi jika melebihi $50 \%$ volume rata-rata, dan dinyatakan rendah jika kurang dari $50 \%$ volume rata-rata permintaan TSR 20. Klasifikasi kondisi harga dan permintaan ini selanjutnya dapat digunakan sebagai masukan untuk model SMA perencanaan produksi pada perekayasaan model keseluruhan.

\section{DAFTAR PUSTAKA}

[1] Direktorat Jenderal Perkebunan, Eksport dan Import in Indonesia,www.ditjenbun.deptan.go.id., 2011.(Diakses pada 3 Desember 2011)

[2] Honggokusumo S., 2011. Proyeksi, Produksi, Konsumsi, Ekspor dan Harga Karet. Makalah disampaikan pada Penyusunan Angka Proyeksi Ekspor Non Migas, Badan Litbang Perdagangan, Jakarta, 2011.

[3] Groover MP., Automation Production System an Integrated Manufacturing. New York: Prentice Hall, 2001.

[4] Indrawanto C., Rekayasa Model Evaluasi Kelayakan Pembiayaan Agroindustri Minyak Atsiri dengan Pola Syariah. Doktoral Disertasi, Bogor: Sekolah Pascasarjana-Institut Pertanian Bogor, 2007.

[5] Surjasa D., Rancang Bangun Model Sistem Penunjang Keputusan Cerdas Untuk Sistem Rantai Pasokan Beras di Propinsi DKI Jakarta, Doktoral Disertasi, Bogor: Sekolah Pascasarjana-Institut Pertanian Bogor, 2011.

[6] Munakata T., Fundamentals of the New Artificial Intelligence: Neural, Evolutionary, Fuzzy and More. Springer-Verlag, London, 2008.

[7] Siang, JJ., Jaringan Syaraf Tiruan dan Pemogramannya Menggunakan Matlab, AndiYogyakarta, 2005. 


\section{Lampiran}

Tabel 1. Pemilihan Arsitektur JST untuk Karet Spesifikasi Teknis (TSR 20)

\begin{tabular}{|c|c|c|c|c|c|c|c|c|c|c|}
\hline \multirow[b]{2}{*}{ No } & \multicolumn{3}{|c|}{ Fungsi Aktivasi } & \multirow{2}{*}{$\begin{array}{c}\text { Algoritma } \\
\text { Training }\end{array}$} & \multicolumn{3}{|c|}{ Indikator yang ingin dicapai } & \multicolumn{3}{|c|}{ Indikator yang dicapai } \\
\hline & $\begin{array}{c}\text { Hidden } \\
\text { Layer }\end{array}$ & $\begin{array}{l}\text { Input - } \\
\text { Hidden }\end{array}$ & $\begin{array}{c}\text { Hidden- } \\
\text { Output }\end{array}$ & & epoch & goal & $\begin{array}{l}\text { Learning } \\
\text { Rate (lr) }\end{array}$ & Epoch & goal & $\begin{array}{l}\text { Regression } \\
\text { (R) }\end{array}$ \\
\hline \multicolumn{11}{|c|}{ Pemilihan jumlah neuron pada hidden layer } \\
\hline 1 & 5 & tansig & purelin & trainrp & 5.000 & $1,00 \mathrm{E}-05$ & 0,001 & 5.000 & $8,84 \mathrm{E}-05$ & 0,97763 \\
\hline 2 & 10 & $\operatorname{tansig}$ & purelin & trainrp & 5.000 & $1,00 \mathrm{E}-05$ & 0,001 & 5.000 & $5,53 \mathrm{E}-05$ & 0,98067 \\
\hline 3 & 15 & tansig & purelin & trainrp & 5.000 & $1,00 \mathrm{E}-05$ & 0,001 & 5.000 & $5,08 \mathrm{E}-05$ & 0,98721 \\
\hline 4 & 20 & tansig & purelin & trainrp & 5.000 & $1,00 \mathrm{E}-05$ & 0,001 & 5.000 & $9,51 \mathrm{E}-05$ & 0,97634 \\
\hline \multicolumn{11}{|c|}{ Pemilihan fungsi aktivasi } \\
\hline 5 & 15 & tansig & purelin & trainrp & 5.000 & $1,00 \mathrm{E}-05$ & 0,001 & 5.000 & $5,08 \mathrm{E}-05$ & 0,98721 \\
\hline 6 & 15 & $\operatorname{tansig}$ & logsig & trainrp & 5.000 & $1,00 \mathrm{E}-05$ & 0,001 & 5.000 & 3,99E-05 & 0,98998 \\
\hline 7 & 15 & $\operatorname{tansig}$ & tansig & trainrp & 5.000 & $1,00 \mathrm{E}-05$ & 0,001 & 5.000 & $5,70 \mathrm{E}-05$ & 0,98565 \\
\hline 8 & 15 & logsig & purelin & trainrp & 5.000 & $1,00 \mathrm{E}-05$ & 0,001 & 5.000 & $5,41 \mathrm{E}-05$ & 0,9864 \\
\hline 9 & 15 & logsig & tansig & trainrp & 5.000 & $1,00 \mathrm{E}-05$ & 0,001 & 5.000 & $5,77 \mathrm{E}-05$ & 0,98548 \\
\hline 10 & 15 & logsig & logsig & trainrp & 5.000 & $1,00 \mathrm{E}-05$ & 0,001 & 5.000 & $4,67 \mathrm{E}-05$ & 0,98826 \\
\hline \multicolumn{11}{|c|}{ Pemilihan algoritma training } \\
\hline 11 & 15 & tansig & logsig & traingda & 5.000 & $1,00 \mathrm{E}-05$ & 0,001 & 5.000 & $5,16 \mathrm{E}-05$ & 0,9869 \\
\hline 12 & 15 & tansig & logsig & traingdx & 5.000 & $1,00 \mathrm{E}-05$ & 0,001 & 5.000 & $3,83 \mathrm{E}-05$ & 0,99038 \\
\hline 13 & 15 & tansig & logsig & traingd & 5.000 & $1,00 \mathrm{E}-05$ & 0,001 & 5.000 & 0,0336 & 0,48291 \\
\hline 14 & 15 & tansig & logsig & traingdm & 5.000 & $1,00 \mathrm{E}-05$ & 0,001 & 5.000 & 0,0898 & 0,21346 \\
\hline 15 & 15 & tansig & logsig & trainlm & 5.000 & 1,00E-05 & 0,001 & 5.000 & 9,19E-06 & 0,9977 \\
\hline
\end{tabular}

Tabel 2.Hasil Prakiraan Harga dan Volume Permintaan Karet jenis TSR 20

\begin{tabular}{ccccccc}
\hline \multirow{2}{*}{ No } & \multicolumn{2}{c}{ Aktual } & \multicolumn{2}{c}{ Prakiraan } & \multicolumn{2}{c}{ Akurasi (\%) } \\
\cline { 2 - 6 } & $\begin{array}{c}\text { Harga } \\
\text { (US cent/kg }\end{array}$ & Volume (lot) & $\begin{array}{c}\text { Harga } \\
\text { (US cent/kg }\end{array}$ & Volume (lot) & $\begin{array}{c}\text { Harga } \\
\text { (US cent/kg }\end{array}$ & Volume (lot) \\
\hline 1 & 296,40 & 183,00 & 310,39 & 123,36 & 95,28 & 67,51 \\
2 & 313,20 & 116,40 & 305,67 & 121,63 & 97,58 & 85,92 \\
3 & 313,42 & 85,83 & 308,17 & 93,56 & 98,33 & 82,11 \\
4 & 322,98 & 79,06 & 316,20 & 81,53 & 97,90 & 90,07 \\
5 & 326,11 & 127,25 & 345,00 & 138,34 & 94,21 & 91,71 \\
6 & 276,16 & 169,01 & 294,32 & 149,78 & 93,42 & 92,76 \\
7 & 294,10 & 67,92 & 294,04 & 61,53 & 99,98 & 94,41 \\
8 & 293,00 & 59,41 & 274,02 & 62,79 & 93,52 & 95,68 \\
9 & 286,97 & 148,22 & 309,50 & 213,52 & 92,15 & 55,94 \\
10 & 306,36 & 90,36 & 295,58 & 98,05 & 96,48 & 91,48 \\
11 & 321,67 & 77,39 & 315,89 & 83,63 & 98,20 & 77,32 \\
12 & 330,74 & 92,81 & 343,94 & 119,98 & 96,01 & 70,73 \\
13 & 361,30 & 104,43 & 353,19 & 91,14 & 97,76 & 87,28 \\
14 & 395,46 & 153,11 & 429,97 & 141,22 & 91,27 & 83,18 \\
15 & 425,23 & 104,23 & 660,58 & 105,12 & 44,66 & 88,67 \\
16 & 441,93 & 103,22 & 311,83 & 71,06 & 70,56 & 68,85 \\
\hline
\end{tabular}

Tabel 3. Kategori Prakiraan Harga dan Volume Permintaan TSR 20

\begin{tabular}{ccc}
\hline Kategori & Harga & Permintaan \\
\hline Tinggi & jika $\mathrm{p}_{1} \geq \mathrm{p}+0,47 \mathrm{p}$ & jika $\mathrm{q}_{1} \geq \mathrm{q}+0,50 \mathrm{q}$ \\
Normal & jika $\mathrm{p}_{1}-0,20 \mathrm{p} \leq \mathrm{p}_{1} \leq \mathrm{p}+0,47 \mathrm{p}$ & Jika $\mathrm{q}-0,50 \mathrm{q} \leq \mathrm{q}_{1} \leq \mathrm{q}+0,50 \mathrm{q}$ \\
Rendah & jika $\mathrm{p}_{1} \leq \mathrm{p}-0,20 \mathrm{p}$ & jika $\mathrm{q}_{1} \leq \mathrm{q}-0,50 \mathrm{q}$ \\
\hline
\end{tabular}

